Matej Bel: Oravská stolica. ed. Nagy, I. - Gergely, T. - Turóci, M. Žilina: Time Print, 2016, 430 pp. ISBN 978-80-89751-10-5

Matej Bel: Liptovská stolica. ed. Turóci, M. - Kordoš, J. Žilina: Time Print, 2015, 391 pp. ISBN 978-80-89751-06-8

Matej Bel: Turčianska stolica. ed. Juriková, E. - Turóci, M. Bratislava: Ultra Print, 2016, 412 pp. ISBN 978-80-89751-15-0

\title{
Marek Škybraha
}

Between 2014-2016, further bilingual editions in the series of Notitia rerum Hungariae novae historico-geografica, the most important work of Matthias Bel, a polymath from the Kingdom of Hungary of Slovak descent, were published. The publications of Liptorská stolica (Liptov County), Oravská stolica (Orava County), and Turčianska stolica (Turiec County), commissioned by the Kysuce Musem in Čadca were published in the "Golden Collection" section with the financial support of the Ministry of Culture of the Slovak Republic. The editors aimed at creating a multifaceted work that would make the historical, biological, geographical and ethnographical data of the individual Hungarian counties in the region of modern-day Slovakia accessible. Historiographers and classical philologists contributed their expertise in compiling these editions. Therefore, the final shape of the individual publications bears the marks of these two fields within humanities and it is these editions that are the subject matter of my report.

I find the inclusion of scientific studies into the introductory parts of the selected editions very helpful, since they provide the reader with the basic overview of the work. In their studies, the authors focus on comparing the individual editions" volumes with the general characteristics of Notitia Hungariae novae historico geographi$c a$, thus enabling the reader to have an overview of the other published editions of Bel's work. The language used in the studies makes them readable for wider public. The authors focus on a broader explanation of the contents of the narrative text alongside the biographical itinerary of the life and work of Matthias Bel, which I noticed in all three editions about the Orava, Liptov and Turiec counties. The philological side of text analysis is dealt with only marginally. Apart from pointing out the occurence of unique Latin terms, predominantly the names of the animal and plant species, a compact textual explication is missing, with the exception of the editions on Liptov and Turiec counties which were almost exclusively compiled by classical philologists. Apart from including the introductory overview, these editions also contain a separate scientific study on the issues of terminology, methodological approaches and linguistic peculiarities of the text presented. The endnotes emphasize the philological approach before the historical context. Based on these comparisons I point out two approaches taken when putting the individual volumes of Matthias Bel's works together, namely the historiographic and philological approach. Both approaches have their strong and weak points. In case of the historiographic approach, what is lacking is deeper philological insights into the source text, however, this is being compensated for by a thorough historical research that strives for enabling the reader to comprehend the historical background and dated terminology. On the other hand, the philological approach undertaken in the editions on Liptov and Turiec counties puts the historical context into the background; however, it does not negatively reflect on the quality of the editors' work on the philological aspect of the text. From the 
reader's point of view, however, this approach makes it more difficult to understand the historical trajectory of the source text. Combining the aforementioned two approaches would, in my opinion, be the ideal way forward when publishing the other volumes of Matthias Bel's work. In doing so, the initial goal of the authors, which was to create textual material that could be used universally and be available to both the scholarly community as well as to wider public, would be achieved, combining the efforts of both historiography and classical philology. The publications on the Liptov and Turiec counties are the harbingers of this trend. There are two kinds of notes used in the publications. In the translation part, the editors limited the notes to listing the source texts from which Matthias Bel compiled his data on the individual counties. The notes pertaining to the translation are to be found at the end of the translation section and serve two purposes; the content part of the notes reveals a thorough philological analysis, since it provides the reader with the information on the selected names of mountain ranges, towns, animals and plants in the text. They also inform the reader on the correct pronunciation, translation methods and their modern-day equivalents. This is a proof that the text was subjected to the critical philological analysis that also includes hints to the classical source material frequently used by Matthias Bel to enliven the text. Providing the text with the notes on translation at the end of the translation part also gives the publications a systematic char- acter, which does not disturb the reader while studying the mirror translation.

The editors' intent to present a bilingual Latin-Slovak translation while preserving the character and textual structure of Bel's original work is thus fulfilled. I greatly appreciate the extensive notes section in the edition on the Orava county. The historical and factual aim of the editor that he had in mind while looking at Bel's work can be clearly seen in the contents of the notes. The emphasis is given to the clarification and explanation of the selected parts of the data bank of the translated text with occasional comments on the philological aspects of the text and it also hints at other possible uses of the classical literary works by Bel himself as well as by the authors and works that were already mentioned in the introductory overview. Compared to the editions on the Liptov and Turiec counties, this edition includes a minimal critical philological analysis.

Apart from the aforementioned facts, the final sections of the editions also contain numerous supplements, such as the chronology of Matthias Bel's works, a detailed name register, the list of the names of towns in the individual counties in Slovak, Hungarian and German language and Slovak, English and German resumes. All the abovementioned facts contribute to the already high quality of the bilingual editions. These editions constitute a succesful publishing feat and are a great way of popularizing the historical and philological scholarship among the academic community as well as wider public.

(transl. Danuša Čižmíková)

Mgr. Marek Škybraha / 491245@mail.muni.cz

Department of Classical Studies

Masaryk University, Faculty of Arts

Arna Nováka 1, 60200 Brno, Czech Republic

Toto dílo Ize užít v souladu s licenčními podmínkami Creative Commons BY-SA 4.0 International (https://creativecommons.org/licenses/by-sa/4.0/legalcode). Uvedené se nevztahuje na díla či prvky (např. obrazovou či fotografickou dokumentaci), které jsou v díle užity na základě smluvní licence nebo výjimky či omezení př́slušných práv. 